\title{
Plasmodium falciparum malaria: another infection of interest to pulmonologists
}

Malária por Plasmodium falciparum: outra infecção de interesse para o pneumologista

\author{
Edson Marchiori, Gláucia Zanetti, Bruno Hochhegger, \\ Clarissa Canella, Klaus Loureiro Irion
}

\section{To the Editor:}

Even though tuberculosis is the major theme on most of the recent articles concerning pulmonary infections published in the Brazilian literature, ${ }^{(1-4)}$ less common infectious diseases have been described and deserve attention. Studies on parainfluenza virus 3 pneumonia, ${ }^{(5)}$ pulmonary cryptosporidiosis, ${ }^{(6)}$ histoplasmosis, ${ }^{(7)}$ and bird fancier's lung ${ }^{(8)}$ have been recently published. We would like to highlight another infection that can cause diffuse lung disease and is common in extensive tropical and subtropical regions: malaria, caused by the protozoan Plasmodium sp.

We report the case of a 38-year-old man born in Amazonas, Brazil, who presented with intermittent fever, chills, dyspnea, and hematuria. Laboratory tests detected anemia and transaminase elevation, and a blood smear was positive for Plasmodium falciparum. A chest X-ray showed bilateral pulmonary infiltrates, whereas CT showed interlobular septal thickening, areas of consolidation, and bilateral pleural effusion, suggestive of pulmonary edema (Figure 1). The patient responded well to antimalarial drugs and was discharged from the hospital after 11 days.

Malaria is a vector-borne disease caused by Plasmodium sp. ( $P$. falciparum, $P$. vivax, $P$. malariae, and $P$. ovale), being responsible for a significant global public health problem. Nearly one million people die annually due to complications of the disease, which is endemic in tropical and subtropical regions. The bite of an infected anopheline mosquito transmits the infectious agent into the bloodstream through the invasion of erythrocytes. The parasitized erythrocytes impair perfusion, nutrition, and oxygen delivery in tissues, especially the brain. ${ }^{(9-11)}$ Infection with P. falciparum may result in potentially lethal complications, including cerebral malaria, acute renal failure, and pulmonary involvement.

Pulmonary manifestations occur in 3-10\% of the patients and range from asymptomatic cases to fatal pulmonary edema caused by capillary leakage. ${ }^{(11)}$ Although patients with uncomplicated malaria usually present with fever and nonspecific symptoms, severe and complicated malaria is characterized by multiorgan involvement, including acute lung injury and acute respiratory distress syndrome (ARDS). ${ }^{(9)}$ Pulmonary edema is a major complication of severe malaria, with a high mortality rate. 1t is often difficult to differentiate between pulmonary edema and ARDS. ${ }^{(10)}$ The development of pulmonary edema in association with malaria characteristically occurs in the absence of cardiac failure or fluid overload.

In patients with acute lung injury/ARDS due to malaria, chest $\mathrm{X}$-rays may reveal bilateral opacities and increased interstitial markings mimicking the pattern observed in patients with ARDS due to other causes. ${ }^{(9)}$ Small pleural effusions may be observed. Pulmonary edema may occur early due to heavy parasitemia or later due to prolonged altered capillary permeability in severe malaria. ${ }^{(11)}$ Malaria is diagnosed parasitologically and is usually confirmed by thick (for parasitemia detection) and thin (for species identification) peripheral blood smear examinations. ${ }^{(9,11)}$ In patients with severe complicated malaria, the early administration of specific antimalarial therapy is life-saving. Quinine and artemisinin derivatives are currently used for the parenteral treatment of severe complicated malaria. ${ }^{(9-11)}$ 


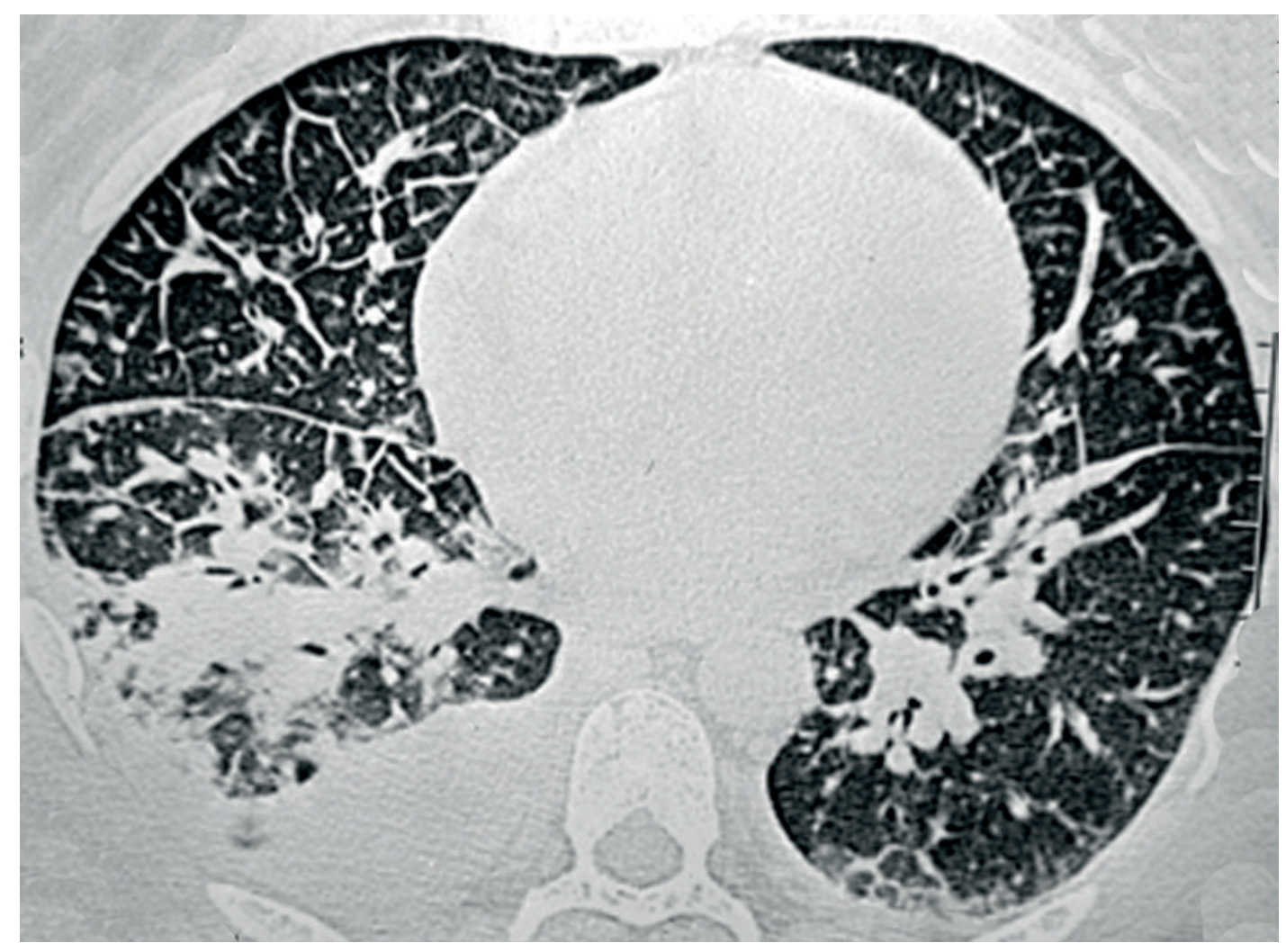

Figure 1 - Axial CT image obtained at the level of the lower lobes and showing interlobular septal thickening, consolidation in the right lung, and bilateral pleural effusion.

Edson Marchiori

Associate Professor of Radiology, Federal University of Rio de Janeiro, Rio de Janeiro, Brazil

\section{Gláucia Zanetti}

Professor, Petrópolis School of Medicine, Petrópolis, Brazil

\section{Bruno Hochhegger}

Radiologist, Santa Casa Hospital

Complex in Porto Alegre, Porto Alegre, Brazil

\section{Clarissa Canella}

Doctoral Student, Graduate Program in Radiology, Federal University of Rio de Janeiro, Rio de Janeiro, Brazil
Klaus Loureiro Irion Radiologist, the Liverpool Heart and Chest Hospital and Liverpool University Hospital, Liverpool, United Kingdom

\section{References}

1. Santos Neto M, da Silva FL, de Sousa KR, Yamamura M, Popolin MP, Arcêncio RA. Clinical and epidemiological profile and prevalence of tuberculosis/HIV co-infection in a regional health district in the state of Maranhão, Brazil. J Bras Pneumol. 2012;38(6):724-32. http://dx.doi. org/10.1590/S1806-37132012000600007 PMid:23288117

2. Ribeiro LB, Magalhães V, Magalhães M. Primary and acquired pyrazinamide resistance in patients with pulmonary tuberculosis treated at a referral hospital in the city of Recife, Brazil. J Bras Pneumol. 2012;38(6):740-7. http://dx.doi.org/10.1590/S1806-37132012000600009 PMid:23288119

3. Traebert J, Ferrer GC, Nazário NO, Schneider 1J, Silva RM. Temporal trends in tuberculosis-related morbidity and mortality in the state of Santa Catarina, Brazil, between 2002 and 2009. J Bras Pneumol. 2012;38(6):771-5. http://dx.doi.org/10.1590/S1806-37132012000600014 PMid:23288124 
4. Telles MA, Menezes A, Trajman A. Bottlenecks and recommendations for the incorporation of new technologies in the tuberculosis laboratory network in Brazil. J Bras Pneumol. 2012;38(6):766-70. http://dx.doi.org/10.1590/ S1806-37132012000600013 PMid:23288123

5. Asai N, Ohkuni Y, Kaneko N, Kawamura Y, Aoshima M. A successfully treated case of parainfluenza virus 3 pneumonia mimicking influenza pneumonia. J Bras Pneumol. 2012;38(6):810-2. http://dx.doi.org/10.1590/ S1806-37132012000600020 PMid:23288130

6. Albuquerque YM, Silva MC, Lima AL, Magalhães V. Pulmonary cryptosporidiosis in AIDS patients, an underdiagnosed disease. J Bras Pneumol. 2012;38(4):530-2. http://dx.doi.org/10.1590/S1806-37132012000400017 PMid:22964939

7. Dall Bello AG, Severo CB, Guazzelli LS, Oliveira FM, Hochhegger B, Severo LC. Histoplasmosis mimicking primary lung cancer or pulmonary metastases. J Bras Pneumol. 2013;39(1):63-8. http://dx.doi.org/10.1590/ S1806-37132013000100009 PMid:23503487

8. Komiya K, lshii H, Tsubone T, Okabe E, Matsumoto B, Kadota J. Bird fancier's lung complicated by pulmonary nocardiosis. J Bras Pneumol. 2013;39(1):102-7. http:// dx.doi.org/10.1590/S1806-37132013000100015 PMid:23503493

9. Mohan A, Sharma SK, Bollineni S. Acute lung injury and acute respiratory distress syndrome in malaria. J Vector Borne Dis. 2008;45(3):179-93. PMid:18807374

10. Mishra SK, Mohanty S, Mohanty A, Das BS. Management of severe and complicated malaria. J Postgrad Med. 2006;52(4):281-7. PMid:17102547

11. Tsang KW, File TM Jr. Respiratory infections unique to Asia. Respirology. 2008;13(7):937-49. http://dx.doi. org/10.1111/j.1440-1843.2008.01409.x PMid:18945321 